\title{
Dampak penerapan protokol kesehatan Coronavirus disease (COVID-19) mencuci tangan terhadap kualitas air permukaan Kota Palangkaraya pada era new normal
}

\author{
Dhymas Sulistyono Putro ${ }^{1}$, Achmad Imam Santoso ${ }^{2^{*}}$ \\ ${ }^{1,2}$ Universitas Muhammadiyah Palangkaraya \\ *Koresponden E-mail: achmadimam2806@gmail.com
}

(Diterima: 15 November 2021|Disetujui: 12 Januari 2022 |Diterbitkan: 31 Januari 2022)

\begin{abstract}
Palangka Raya City is one of the cities affected by COVID-19, where on November 11, 2021, and 13104 people were confirmed positive for COVID-19. The Health Protocol continues to be carried out in this New Normal era. The Health Protocol by washing hands with soap is an environmental issue that needs attention, namely the use of hand soap which reduces surface air quality. Hand soap contains chemicals that can increase the concentration of Chemical Oxygen Demand (COD). There is a need for laboratory testing of the COD parameters of surface water around handwashing facilities in public facilities in the era of new habits. The research was divided into laboratory tests on surface water parameters, namely $\mathrm{pH}$, temperature, and COD as well as field surveys on the use of handwashing facility. The results of laboratory tests show that the quality of surface water on the COD parameter is below the quality standard. The use of handwashing facilities is not justified, because its use is only 19\%. Along with the low use of handwashing facilities, hand washing facilities do not have an impact on decreasing surface water quality on the COD parameter, it can be an action to maintain surface water quality.
\end{abstract}

Keywords: COVID-19; health protocol; handwashing facility; COD

\section{PENDAHULUAN}

Pandemi COVID-19 telah terjadi selama kurang lebih 2 tahun. Selama 2 tahun kebelakang, seluruh aktivitas masyarakat dibatasi, sehingga menimbulkan dampak terhadap berbagai sector (Bakri, 2020) \& (Muzakki, 2020). Kota Palangka Raya merupakan salah satu kota yang terdampak oleh COVID-19, dimana per tanggal 11 November 2021 telah terkonfirmasi positif COVID-19 sejumlah 13104 jiwa. Agar dapat meminimalisir penyebaran COVID19, pemerintah menerapkan kebijakan protokol Kesehatan dalam beraktivitas. Pembatasan aktivitas ini diterapkan dalam bentuk kegiatan Pembatasan Sosial Berskala Besar (PSBB) dan Pemberlakuan Pembatasan Kegiatan Masyarakat (PPKM). Kegiatan pembatasan ini tidak mampu memberikan pengaruh besar terhadap peningkatan berbagai sektor, sehingga diberlakukannya pembatasan secara bertingkat dalam melaksanakan aktivitas dengan tetap mematuhi protokol Kesehatan (Adriansyah et al., 2021), (Hartawan et al., 2021), \& (Toharudin et al., 2021).

Protokol Kesehatan yang wajib diterapkan dalam rangka penanggulangan penyebaran COVID-19 yaitu menggunakan masker, menjaga jarak, mengurangi mobilitas, mengindari keramaian, serta mencuci tangan menggunakan sabun (Adam, et al., 2021). Protokol Kesehatan tersebut terus dilakukan pada saat era kebiasaan baru (New Normal) ini. Era kebia- saan baru merupakan kembali beraktivitasnya masyarakat untuk menggerakkan berbagai sektor yang disertai dengan penerapan protokol kesehatan diatas. Pada era kebiasaan baru ini banyak hal yang perlu dipersiapkan, diantaranya kebijakan atau peraturan serta fasilitas pendukung dalam penanggulangan COVID-19. Beberapa fasilitas pendukung diantaranya yaitu fasilitas bagi masyarakat yang terjangkit COVID-19 maupun pelaksanaan protokol kesehatan COVID-19.

Fasilitas pendukung diperlukan dalam penerapan protokol kesehatan pada kebiasaan baru. Sehingga, pada tempat dan fasilitas umum merupakan salah satu fokus masyarakat beraktivitas yang akan mendukung keberlangsungan aktivitas, namun berpotensi pula menjadi fokus penyebaran COVID-19, sehingga diperlukan protokol kesehatan dalam pelaksanaan kegiatan di tempat dan fasilitas umum (Ambarawati \& Darma, 2021). Salah satunya yaitu adanya fasilitas cuci tangan di tempat dan fasilitas umum dalam menunjang protokol Kesehatan mencuci tangan menggunakan sabun (Mujani \& Irvani, 2020). Protokol Kesehatan dengan mencuci tangan menggunakan sabun menimbulkan permasalahan lingkungan yang perlu diperhatikan, yaitu penggunaan sabun cuci tangan yang berpotensi menurunkan kualitas air permukaan. Sabun cuci tangan mengandung zat kimia yang berpotensi meningkatkan konsentrasi Chemical Oxygen Demand (COD) (Yogafanny, 2015) (Rachmawati, et al., 2020). COD memiliki dampak buruk 
terhadap lingkungan, yaitu ketersediaan oksigen (O2) semakin menipis, sehingga mengancam kehidupan biota air (Rosyid, et al., 2021). Sedangkan pada manusia, akan munculnya pathogen yang berpotensi menimbulkan berbagai penyakit (Sumantri \& Cordova, 2011). Dengan demikian, perlu dilakukannya pengujian laboratorium pada parameter COD air permukaan di sekitar tempat cuci tangan di fasilitas umum pada saat era kebiasaan baru. Sehingga, dapat mengidentifikasi dampak keberadaan fasilitas cuci tangan terhadap kualitas air permukaan serta solusi yang dapat diterapkan dalam menjaga kualitas air permukaan khususnya pada parameter COD saat era kebiasaan baru.

\section{BAHAN DAN METODE}

Pelaksanaan penelitian ini terbagi atas uji laboratorium dan pengamatan lapangan yang dilaksanakan pada Pasar Jl. G. Obos Kota Palangka Raya pada rentang waktu Mei hingga September 2021.

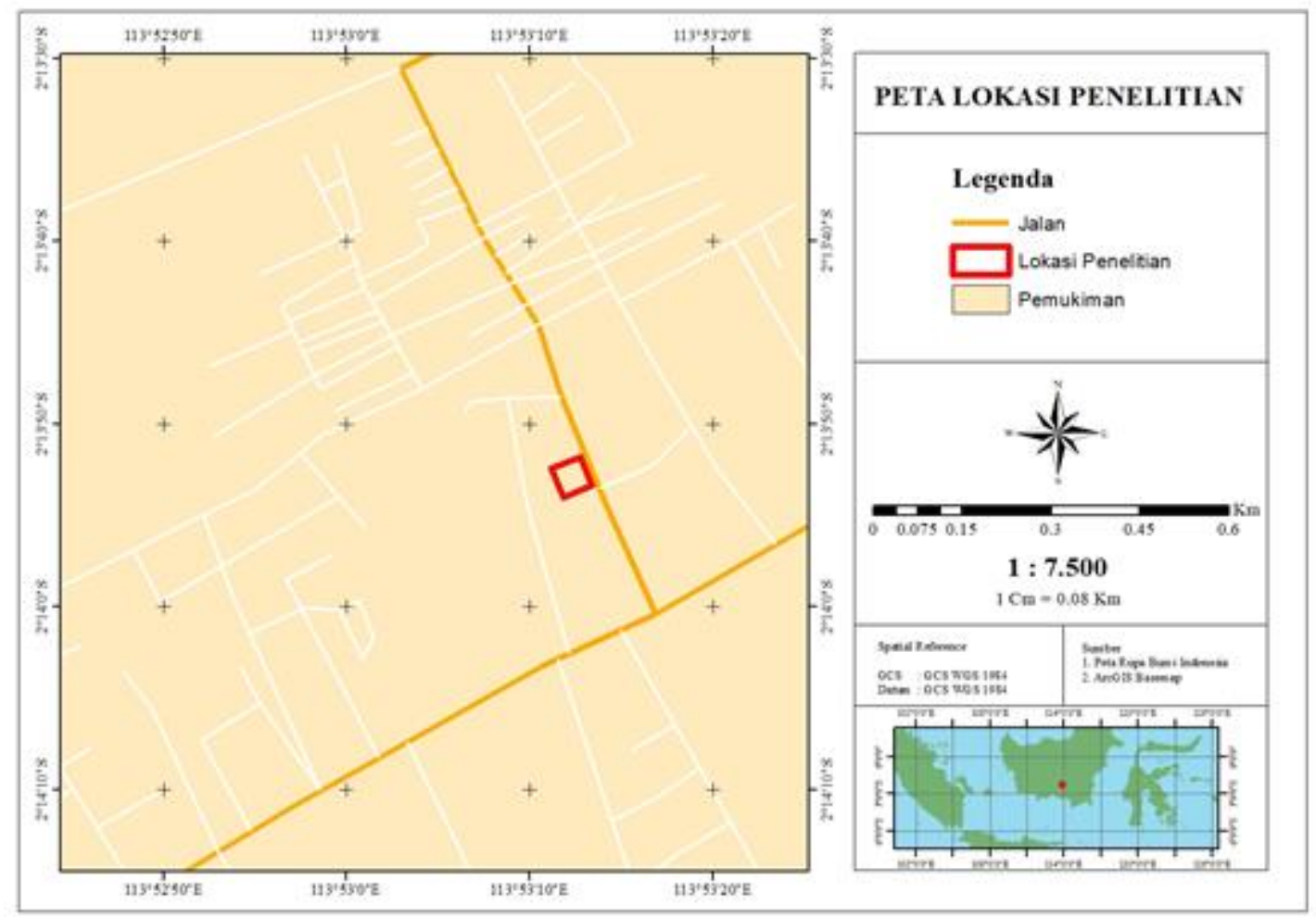

Gambar 1. Peta Lokasi Penelitian

\section{Uji Laboratorium}

Pengujian laboratorium dilakukan pada Laboratorium Fakultas Teknik dan Informatika UM Palangka Raya dan Laboratorium Kesehatan Daerah Kota Palangka Raya. Parameter yang digunakan dalam uji laboratorium yaitu $\mathrm{pH}$, suhu, dan $\mathrm{COD}$, dimana pengambilan sampel dilakukan pada sekitar tempat cuci tangan yang telah disediakan oleh pemerintah di Pasar Jl. G. Obos Kota Palangka Raya sebanyak 3 kali pengulangan. Hasil pengujian laboratorium ini selanjutnya dilakukan analisis perbandingan terhadap baku mutu yang telah tertera pada PP No. 2 Tahun 2021 serta perbandingan terhadap hasil uji laboratorium saat awal pandemi COVID-19.

\section{Survei Lapangan}

Survei lapangan dilakukan selama 3 hari terhadap 50 orang yang menggunakan fasilitas cuci tangan pemerintah pada Pasar J1. G. Obos Kota Palangka Raya. Penggunaan ceklist bertujuan untuk menge- tahui jumlah pengguna fasilitas cuci tangan yang telah disediakan pemerintah yang selanjutnya dipersentasekan dalam tingkat penggunaan. Berikut Tabel 1. Tingkat Penggunaan Fasilitas Cuci Tangan:

Tabel 1. Tingkat Penggunaan Fasilitas Cuci Tangan Tingkat Penggunaan $\quad$ Persentase (\%)

\begin{tabular}{ll}
\hline Tidak Pernah & $0-20,99$ \\
Jarang & $21-40,99$ \\
Kadang-Kadang & $41-60,99$ \\
Sering & $61-80,99$ \\
Selalu & $81-100$ \\
\hline
\end{tabular}

HASIL DAN PEMBAHASAN

\section{Hasil Uji Laboratorium}

Hasil pengujian laboratorium menunjukkan dilakukan terhadap tiga parameter kualitas air permukaan. Pada COD, berada diatas nilai 80 sebagai 
baku mutu yang berlaku sebesar 89,53. Pada Suhu berada pada dibawah baku mutu yang berlaku, yaitu 27,67. Sedangkan pada $\mathrm{pH}$ berada pada ambang batas baku mutu, dengan demikian pada parameter tersebut dikategorikan sesuai dengan peraturan yang berlaku. Lebih jelasnya, tertera pada Tabel 2.

Tabel 2. Hasil Uji Laboratorium

\begin{tabular}{llllll}
\hline \multirow{2}{*}{ Parameter } & \multicolumn{3}{c}{ Sampel } & $\begin{array}{l}\text { Rata- } \\
\text { Rata }\end{array}$ & $\begin{array}{l}\text { Baku } \\
\text { Mutu }\end{array}$ \\
\cline { 2 - 4 } & A1 & A2 & A3 & & \\
\hline COD & 89,7 & 89,1 & 89,8 & 89,53 & 80 \\
pH & 6 & 7 & 5 & 6 & $6-9$ \\
Suhu & 27 & 28 & 28 & 27,67 & 28 \\
\hline
\end{tabular}

Perbandingan Hasil Uji Laboratorium Terhadap Penelitian Terdahulu

Hasil uji laboratorium memiliki nilai yang lebih baik dibandingkan pada penelitian terdahulu pada lokasi yang sama (Santoso, 2020). Terlihat pada parameter COD hasil uji laboratorium saat memiliki nilai lebih mendekati baku mutu dibandingkan hasil uji laboratorium pada penelitian terdahulu. Sehingga, kualitas air permukaan pada parameter COD pada hasil uji laboratorium saat ini lebih baik dibandingkan hasil uji laboratorium pada penelitian terdahulu.

Parameter $\mathrm{pH}$ dan Suhu cenderung berada tidak jauh dari baku mutu, sehingga tidak ada perbedaan secara signifikan terhadap kualitas air permukaan Pasar J1. G. Obos Kota Palangka Raya saat awal pandemi COVID-19 maupun saat era new normal. Referensi Perbandingan uji laboratorium terhadap Penelitian terdahulu terlihat pada Tabel 3 berikut.

Tabel 3. Perbandingan Uji Laboratorium

\begin{tabular}{llll}
\hline Parameter & $\begin{array}{c}\text { Sampel } \\
\text { Saat Ini }\end{array}$ & $\begin{array}{c}\text { Sampel Penelitian } \\
\text { Terdahulu }\end{array}$ & $\begin{array}{l}\text { Baku } \\
\text { Mutu }\end{array}$ \\
\hline COD & 89,53 & 101,23 & 80 \\
pH & 6 & 6,3 & $6-9$ \\
Suhu & 27,67 & 26,67 & 28 \\
\hline
\end{tabular}

Penggunaan Fasilitas Cuci Tangan Umum Protokol Kesehatan COVID-19

Mencuci tangan merupakan salah satu Protokol Kesehatan dalam menangggulangi penyebaran COVID-19 (Hermawati et al., 2021) (Rianto, et al., 2020). Pada Tabel 4, terdapat 150 orang responden yang terbagi selama tiga hari pengamatan. Responden yang melakukan mencuci tangan hanya sebanyak 28 orang, sedangkan yang tidak mencuci tangan sebanyak 122 orang. Jika dilakukan persentase pada keduanya, mencuci tangan hanya 19\% sedangkan tidak mencuci tangan sebesar $81 \%$ seperti pada Gambar 1, sehingga dikategorikan tingkat penggunaan tidak pernah. Dengan demikian, mayoritas masyarakat cenderung tidak menggunakan fasilitas cuci tangan yang telah disediakan.
Tabel 4. Hasil Pengamatan Penggunaan Fasilitas Cuci Tangan

$\begin{array}{ccc}\text { Waktu } & \text { Mencuci Tan- } & \text { Tidak Mencuci } \\ & \text { gan } & \text { Tangan }\end{array}$

\begin{tabular}{lll}
\hline Hari ke-1 & 7 & 43 \\
Hari ke-2 & 8 & 42 \\
Hari ke-3 & 13 & 37 \\
Jumlah & 28 & 122 \\
\hline
\end{tabular}

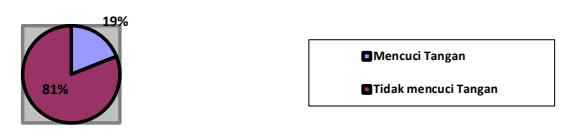

Gambar 2. Persentase Penggunaan Fasilitas Cuci Tangan

\section{Hubungan Kualitas Air Permukaan dan Fasilitas Cuci Tangan}

Paramater kualitas air cuci yang digunakan pada penelitian ini yaitu COD, $\mathrm{pH}$, dan Suhu. Adanya fasilitas cuci tangan di Pasar J1. G. Obos Kota Palangka Raya akan berpotensi menurunkan kualitas air permukaan (Wahyuni \& Sugito, 2016). Sabun cuci tangan yang digunakan dapat menurunkan kualitas air permukaan, terutama dalam parameter COD dan pH (Lestari, et al., 2018). Berdasarkan hasil uji laboratorium saat ini dan penelitian terdahulu terjadi penurunan pada parameter COD. Hal ini dikarenakan menurunnya penggunaan fasilitas cuci tangan (Puspita et al., 2016) (Yulistia, 2020). Penurunan ini didukung oleh hasil survei lapangan dengan hasil tingkat penggunaan tidak pernah. Hal ini dipengaruhi adanya berbagai pilihan masyarakat dalam mencuci tangan, seperti menggunakan hand sanitizer maupun tisu basah yang dapat dibawa kemana saja (Mustakim, et al., 2020) (Nakoe, et al., 2020). Seiring rendahnya penggunaan fasilitas cuci tangan tersebut, dengan demikian fasilitas cuci tangan tidak berdampak terhadap penurunan kualitas air permukaan pada parameter COD, justru dapat menjadi salah satu solusi dalam menjaga kualitas air permukaan.

\section{KESIMPULAN}

Adanya fasilitas cuci tangan di Pasar G. Obos Kota Palangka Raya memengaruhi kualitas air permukaan, terutama pada parameter COD saat awal pandemi maupun saat era kebiasaan baru. Saat era kebiasaan baru, masyarakat cenderung menggunakan fasilitas cuci tangan yang dapat dibawa kemana saja. Dengan demikian, kualitas air permukaan pada parameter COD akan terjaga karena penurunan penggunaan fasilitas cuci tangan seiring peralihan masyarakat menggunakan fasilitas cuci tangan yang dapat dibawa kemana saja. Sehingga, minimnya 
penggunaan fasilitas cuci tangan yang disediakan pemerintah mampu menjaga kualitas air permukaan.

\section{UCAPAN TERIMAKASIH}

Kami mengucapkan terima kasih kepada pihak Universitas Muhammadiyah Palangka Raya atas bantuan dana penelitian yang disalurkan melalui Lembaga Penelitian dan Pengabdian Masyarakat Universitas Muhammadiyah Palangka Raya yang tercantum pada SK Rektor Universitas Muhammdiyah Palangka Raya No. 182/PTM63.R/SK/N/2021.

\section{DAFTAR PUSTAKA}

Adam, S., Supusepa, R., Hattu, J., Taufik, I. (2021). Penegakan Hukum Terhadap Pelanggaran Protokol Kesehatan yang Dilakukan Masyarakat Pada Masa Pandemi Covid-19 di Kota Ambon. SASI, 27(2): 230-246. DOI: https://doi.org/10.47268/sasi.v27i2.441

Adriansyah, D., Utomo, A. P., Aisyah, S., Christiyanti, R. D., Sholehah., Harvianti, E. (2021). The Impact Of The Covid-19 Pandemic On The Economy In North Kalimantan Province, Indonesia. Russian Journal Of Agricultural And SocioEconomic Sciences, 5(113): 3-15. https://doi.org/10.18551/rjoas.2021-05.01

Ambarawati, D. A., Darma, I. M. W. (2021). Strategi Komunikasi Satgas Covid-19 Dalam Memberikan Sosialisasikan Prokes Kepada Lansia Di Desa Penatahan. Kaibon Abhinaya, 3(2): 95-98. https://doi.org/10.30656/ka.v3i2.3143

Bakri, H. (2020). Quality Improvement of Community Health Center During Covid-19 Pandemic. International Journal of Multicultural and Multireligious Understanding, 7(4): 345-354. https://doi.org/10.18415/ijmmu.v7i4.1614

Hartawan, I G. N. B. R. M., Sastrawan, I G. G., Parastan, R. H., Ani, L. S. (2021). Depression, anxiety, and stress levels in Denpasar community during the pandemic of Corona Virus Disease 2019 (COVID-19). Qanun Medika: Jurnal Kedokteran Fakultas Kedokteran Universitas Muhammadiyah Surabaya, 5(1): 103-111. DOI: http://dx.doi.org/10.30651/jqm.v5i1.5177

Hermawati, B., Handayani, O. W. K., Mahendrasari, D. S., Mukti, F. A., Wijayanti, A. (2021). Edukasi Kesehatan Mengenai Praktik Cuci Tangan pada Guru sebagai Upaya Pencegahan Covid-19. Jurnal Obsesi: Jurnal Pendidikan Anak Usia Dini, 6(2): 894-902. DOI: 10.31004/obsesi.v6i2.1060

Santoso, A. I. (2020). Analisis Dampak Implementasi Kebijakan Kementrian Kesehatan tentang Protokol Kesehatan Selama Covid-19 terkait Cuci Tangan dengan Sabun terhadap Kualitas Air di Fasilitas Umum Palangkaraya. Laporan Akhir Hibah Riset Muhammadiyah Skema Covid-19. Palangkaraya
Lestari, R. K., Amalia, E., Yuwono. (2018). Efektivitas Jeruk Nipis (Citrus Aurantifolia Swingle) Sebagai Zat Antiseptik Pada Cuci Tangan. Jurnal Kedokteran dan Kesehatan, 5(2): 55-65. DOI: https://doi.org/10.32539/JKK.v5i2.6126

Mujani, S., Irvani, D. (2020). Sikap dan Perilaku Warga terhadap Kebijakan Penanganan Wabah Covid-19. POLITIKA: Jurnal Ilmu Politik, 11(2): 219-238. https://doi.org/10.14710/politika.11.2.2020.219238

Mustakim, Z., Purwaningtyas, F. Y., Irsadi, R. S. (2020). Pembuatan dan Pembagian Hand Sanitizer Sebagai Upaya Pencegahan Covid-19 di Desa Dahan Rejo Lor Kabupaten Gresik. DedikasiMu (Journal of Community Service), 2 (3): 482-487. DOI: http://dx.doi.org/10.30587/dedikasimu.v2i 3.1653

Muzakki, F. (2020). The Global Political Economy Impact Of Covid-19 And The Implication To Indonesia. Journal of Social Political Sciences, 1(2): 76-93. http://e- journal.unas.ac.id/index.php/jsps/article/view/11

Nakoe, R., Lalu, N. A. S., Mohamad, Y. A. (2020). Perbedaan Efektivitas Hand-Sanitizer Dengan Cuci Tangan Menggunakan Sabun Sebagai Bentuk Pencegahan Covid-19. Jambura (Journal of Health Sciences and Research), 2(2): 65-70. DOI: https://doi.org/10.35971/jjhsr.v2i2.6563

Puspita, I., Ibrahim, L., Hartono, D. (2016). Pengaruh Perilaku Masyarakat Yang Bermukim Di Kawasan Bantaran Sungai Terhadap Penurunan Kualitas Air Sungai Karang Anyar Kota Tarakan. Jurnal Manusia dan Lingkungan, 23(2): $49-258$ https://doi.org/10.22146/jml.18797

Rachmawati, I. P., Riani, E., Riadi, A. (2020). Status Mutu Air dan Beban Pencemaran Sungai Krukut, DKI Jakarta. Jurnal Pengelolaan Sumber Daya Alam dan Lingkungan (JPSL), 10(2): 220-233. http://dx.doi.org/10.29244/jps1.10.2.220-233

Rianto, A., Wildanu, E., Afnan, D. (2020). Upaya Masyarakat Pedesaan Melawan Covid-19 Ditinjau Dari Aspek Sosiologis. Jurnal Soshum Insentif, 3(2):180-187.

DOI: https://doi.org/10.36787/jsi.v3i2.277

Rosyid, L. M. A., Titah, H. S., Santoso, I. B., Mangkoedihardjo, S. (2021). Review on BOD/COD Ratio Toxicity to Daphnia magna, Artemia salina, and Brachydanio rerio. Nature Environment and Pollution Technology, 20(4): 1741-1748. https://doi.org/10.46488/NEPT.2021.v20i04.039

Sumantri, A., Cordova, M. R. (2011). Dampak Limbah Domestik Perumahan Skala Kecil Terhadap Kualitas Air Ekosistem Penerimanya Dan Dampaknya Terhadap Kesehatan Masyarakat. Jurnal Pengelolaan Sumberdaya Alam Dan Lingkungan (JPSL), 1(2): 127-134. DOI: https://doi.org/10.29244/jpsl.1.2.127 
Toharudin, T., Pontoh, R. S., Caraka, R. E., Zahroh, S., Kendogo, P., Sjiabat, N., Sari, M. D. P., Gio, P. U., Basyuni, M., Pardamean, B. (2021). National Vaccination and Local Intervention Impacts on COVID-19 Cases. SUSTAINABILITY, 13(8282):

https://doi.org/10.3390/su13158282

Wahyuni, S., Sugito. (2016). Pengaruh Penggunaan Koagulan Pada Biofilter Anaerobik Aerobik Dalam Menurunkan COD (Chemical Oxygen Demand) dan BOD (Biological Oxygen Demand) Limbah Cair Industri Farmasi.Waktu: Jurnal Teknik UNIPA, 13(1): 1-9.

https://doi.org/10.36456/waktu.v13i1.25
Yogafanny, E. (2015). Pengaruh Aktifitas Warga di Sempadan Sungai terhadap Kualitas Air Sungai Winongo. Jurnal Sains dan Teknologi Lingkungan, $\quad 7(1)$ : 41-50. DOI: https://doi.org/10.20885/jstl.vol7.iss1.art3 Yulistia, E. (2020). Dampak Kegiatan Masyarakat di Sempadan Sungai Terhadap Kualitas Air Sungai Ogan di Kota Baturaja Kabupaten OKU. UEEJUnbara Environment Engineering Journal, 1(1). http://journal.unbara.ac.id/index.php/UEEJ/arti cle/view/735 